\title{
Hydration, carbonation and thermal stability of hydrates in $\mathrm{Ca}_{7-\mathrm{x}} \mathrm{Sr}_{\mathrm{x}} \mathrm{ZrAl}_{6} \mathrm{O}_{18}$ cement
}

\author{
Dominika Madej ${ }^{1}$
}

Received: 1 July 2017/Accepted: 18 September 2017/Published online: 3 October 2017

(c) The Author(s) 2017. This article is an open access publication

\begin{abstract}
This paper studies hydration stages and phase transformation mechanism of the $\mathrm{Sr}^{2+}$-doped calcium zirconium aluminate cement at room temperature. Features of different hydration stages of this cement paste are identified by X-ray diffraction, scanning electron microscopy, differential thermal analysis, thermogravimetric analysis, evolved gas analysis and heat evolution test. It was found that the partial isovalent substitution of $\mathrm{Ca}^{2+}$ for $\mathrm{Sr}^{2+}$ such as $\mathrm{Ca}_{7-\mathrm{x}} \mathrm{Sr}_{\mathrm{x}} \mathrm{ZrAl}_{6} \mathrm{O}_{18}$, with $x=0.3,0.6,1.0$, reduced the hydraulic reactivity of $\mathrm{Ca}_{7} \mathrm{ZrAl}_{6} \mathrm{O}_{18}$ phase. The course of hydration of mixed oxides of the type $6 \mathrm{CaO} \cdot \mathrm{SrO} \cdot 3 \mathrm{Al}_{2} \mathrm{O}_{3}$. $\mathrm{ZrO}_{2}$ documented using microcalorimetry was supported by investigations of the solid hydration products. Research showed that the hexagonal hydrates were stable at early and middle curing ages, an indication that including $\mathrm{Sr}$ in solid solution could effectively inhibit the conversion from both $\mathrm{C}_{4} \mathrm{AH}_{13-19}$ and $\mathrm{C}_{2} \mathrm{AH}_{8}$ to $\mathrm{C}_{3} \mathrm{AH}_{6}$ and $\mathrm{AH}_{3}$. Calcium monocarboaluminate $\mathrm{C}_{4} \mathrm{AC} \mathrm{CH}_{11}$ phases were also found in this system due to the carbonation process of $\mathrm{C}_{4} \mathrm{AH}_{13}$ phase. Substitution of $\mathrm{Ca}^{2+}$ ions by $\mathrm{Sr}^{2+}$ ions in hexagonal calcium aluminate hydrates causes structural disorder and then contributes to the broadening of lines in the powder X-ray diffraction patterns of layered structures of metastable hydrates. At later curing ages, the formation of two hydrogarnet phases, one Sr-rich $(\mathrm{C}, \mathrm{Sr})_{3} \mathrm{AH}_{6}$ and the other Ca-rich $(\mathrm{C}, \mathrm{Sr})_{3} \mathrm{AH}_{6}$, was proved.
\end{abstract}

Dominika Madej

dmadej@agh.edu.pl

1 Department of Ceramics and Refractories, Faculty of Materials Science and Ceramics, AGH University of Science and Technology, al. A. Mickiewicza 30, 30-059 Kraków, Poland
Keywords Sr-doped calcium zirconium aluminate $\left(\mathrm{Ca}_{7} \mathrm{ZrAl}_{6} \mathrm{O}_{18}\right) \cdot$ Hydraulic activity $\cdot$ Structure modifications - Carbonation - Heat flow calorimetry

\section{Introduction}

Calcium aluminates, i.e. calcium monoaluminate $\left(\mathrm{CaAl}_{2}\right.$ $\left.\mathrm{O}_{4}, \mathrm{CA}\right)$, calcium dialuminate $\left(\mathrm{CaAl}_{4} \mathrm{O}_{7}, \mathrm{CA}_{2}\right)$ and dodecacalcium hepta-aluminate or mayenite $\left(\mathrm{Ca}_{12} \mathrm{Al}_{14} \mathrm{O}_{33}\right.$, $\mathrm{C}_{12} \mathrm{~A}_{7}$ ), are the most important constituents of hydraulic calcium aluminate cements (CACs) $[1,2]$. Calcium zirconium aluminate $\left(\mathrm{Ca}_{7} \mathrm{ZrAl}_{6} \mathrm{O}_{18}, \mathrm{C}_{7} \mathrm{~A}_{3} \mathrm{Z}\right)$ is considered to be only a chemical compound containing zirconium $(\mathrm{Zr})$ in $\mathrm{CaO}-\mathrm{Al}_{2} \mathrm{O}_{3}-\mathrm{ZrO}_{2}$ system that exhibits hydraulic reactivity similar to tricalcium aluminate $\left(\mathrm{Ca}_{3} \mathrm{Al}_{2} \mathrm{O}_{6}, \mathrm{C}_{3} \mathrm{~A}\right)$ [3-5]. It is also well known that the hydraulic reactivity of these phases increases with the calcium content of the phase $\left(\mathrm{CaO} / \mathrm{Al}_{2} \mathrm{O}_{3}\right.$ molar ratio), and therefore, $\mathrm{C}_{7} \mathrm{~A}_{3} \mathrm{Z}$ shows higher reactivity than mineral phases of CACs. The formation and dehydration of a number of $\mathrm{C}-\mathrm{A}-\mathrm{H}$-like phases of hydrated $\mathrm{Ca}_{7} \mathrm{ZrAl}_{6} \mathrm{O}_{18}$ were investigated in previous works [6-12].

The hydration process of the calcium aluminate cement produces similarly the various forms of hydrated calcium aluminate and gibbsite. Dissolution of the anhydrous phases causes a significant increase in concentration of $\mathrm{Ca}^{2+}$, $\mathrm{Al}(\mathrm{OH})_{4}^{-}$and $\mathrm{OH}^{-}$ions [13]. The precipitation and growth of the hydrates takes place through the solution. When supersaturation is reached, calcium and aluminium ions can combine in variable ratios to precipitate different hydrates $\mathrm{CAH}_{10}, \mathrm{C}_{2} \mathrm{AH}_{8}, \mathrm{C}_{4} \mathrm{AH}_{19}, \mathrm{C}_{4} \mathrm{AH}_{13}, \mathrm{C}_{3} \mathrm{AH}_{6}$ and $\mathrm{AH}_{3}$ $\left(\mathrm{C} \equiv \mathrm{CaO}, \quad \mathrm{A} \equiv \mathrm{Al}_{2} \mathrm{O}_{3}, \mathrm{H} \equiv \mathrm{H}_{2} \mathrm{O}\right)$. These processes proceed with time and exhibit the temperature dependence [14]. The $\mathrm{C}_{2} \mathrm{AH}_{8}$ and $\mathrm{C}_{4} \mathrm{AH}_{19}$ belong to the broad AFm 
phases with the general formula $\left[\mathrm{Ca}_{2}(\mathrm{Al}, \mathrm{Fe})(\mathrm{OH})_{6}\right]-$ $\mathrm{X} \cdot \mathrm{xH}_{2} \mathrm{O}$, where $\mathrm{X}$ is one formula unit of a singly charged anion (e.g. $\mathrm{OH}^{-}$) or half a formula unit of a doubly charged anion (e.g. $\mathrm{CO}_{3}^{2-}$ ). These crystals have a layered structure consisting of positively charged $\left[\mathrm{Ca}_{2} \mathrm{Al}(\mathrm{OH})_{6}\right]^{+}$sheets with $\mathrm{Al}(\mathrm{OH})_{4}^{-}$or $\mathrm{OH}^{-}$, together with $\mathrm{H}_{2} \mathrm{O}$ in the interlayer region. $\mathrm{C}_{4} \mathrm{AH}_{19}$ contains a complete additional layer of $\mathrm{H}_{2} \mathrm{O}$ between the principle layers. $\mathrm{C}_{4} \mathrm{AH}_{19}$ can lose part of its interlayer water molecules to form $\mathrm{C}_{4} \mathrm{AH}_{13}$ at relative humidity below $88 \%$. The initially formed metastable hexagonal hydrates are generally transformed into stable $\mathrm{C}_{3} \mathrm{AH}_{6}$ belonging to the regular system. The factors controlling transformation are: time, temperature, water content and $\mathrm{CO}_{2}$ content in the system. In the presence of atmospheric $\mathrm{CO}_{2}$, part of the interlayer $\mathrm{OH}^{-}$can be replaced by $\mathrm{CO}_{3}^{2-}$ via interlayer exchange to form two representative carbon-containing $\mathrm{AFm}$ phases: stable monocarboaluminate $\mathrm{C}_{3} \mathrm{~A} \cdot \mathrm{CaCO}_{3} \cdot 11 \mathrm{H}_{2} \mathrm{O}$ $\left(\mathrm{C}_{4} \mathrm{~A} \overline{\mathrm{C}} \mathrm{H}_{11} ; \overline{\mathrm{C}}=\mathrm{CO}_{2}\right)$, which contains only $\mathrm{CO}_{3}^{2-}$ anions in the $\mathrm{X}$ position, and unstable hemicarboaluminate $\mathrm{C}_{3} \mathrm{~A} \cdot 0.5 \mathrm{CaCO}_{3} \cdot 0.5 \mathrm{Ca}(\mathrm{OH})_{2} \cdot 11.5 \mathrm{H}_{2} \mathrm{O}\left(\mathrm{C}_{4} \mathrm{AC}_{0.5} \mathrm{H}_{12}\right)$, which contains both $\mathrm{OH}^{-}$and $\mathrm{CO}_{3}^{2-}$ anions in the $\mathrm{X}$ position of hexagonal hydrates [15].

Due to a poor crystallinity of the hydration products formed at early age hydration and low water-to-cement ratio (w/c) or overlapping peaks due to hydrates with distinct but closely related crystallographic characteristics from a complex XRD profile, the methods of combined thermal analysis (DTA-TG-EGA) are promising ones regarding their qualitative and quantitative characterization. Previous works [16-27] indicated various decomposition temperatures of $\mathrm{Ca}-\mathrm{Al}$ hydrates, obtained by thermal analysis methods. According to both Fleisher [16] and Hill [17], $\mathrm{C}_{4} \mathrm{AH}_{13-19}$ phase decomposes in the temperature range $200-280{ }^{\circ} \mathrm{C}$ or at a temperature of $250{ }^{\circ} \mathrm{C}$, respectively. $\mathrm{C}_{4} \mathrm{~A} \overline{\mathrm{C}} \mathrm{H}_{11}$ and $\mathrm{C}_{2} \mathrm{AH}_{8}$ do indeed give DTA peaks in the same temperature range $160-200{ }^{\circ} \mathrm{C}$ [18]. George [19] reports an endothermic peak due to dehydration of $\mathrm{C}_{2} \mathrm{AH}_{8}$ at $170{ }^{\circ} \mathrm{C}$. Various authors [9, 20-27] have reported DTA curves including evidence for the presence stable cubic $\mathrm{C}_{3} \mathrm{AH}_{6}$. All report an endothermic peak due to dehydration somewhere in the range $300-330{ }^{\circ} \mathrm{C}$. The products of hydration will also include alumina gel $\left(\mathrm{AH}_{3}\right.$-gel $)$ and gibbsite $\mathrm{Al}(\mathrm{OH})_{3}$ that decompose below $120^{\circ} \mathrm{C}$ [18] and at a temperature of around 275 or $280^{\circ} \mathrm{C}[19,20]$, respectively.

It can be strongly argued that the importance of inorganic hydraulic binders is only exceeded by our lack of knowledge as to the factors influencing the synthesis, structures and properties of the calcium aluminates in CACs and calcium zirconium aluminate. One approach to developing this group of materials that can be taken is to examine the effect dopant cations, e.g. $\mathrm{Sr}^{2+}$, have on the properties and the hydraulic activity of
$\mathrm{Ca}_{7} \mathrm{ZrAl}_{6} \mathrm{O}_{18}$. Some series of oxides $\mathrm{Ca}_{1-\mathrm{x}} \mathrm{Sr}_{\mathrm{x}} \mathrm{Al}_{2} \mathrm{O}_{4}$ and $\mathrm{Ca}_{3-\mathrm{x}} \mathrm{Sr}_{\mathrm{x}} \mathrm{Al}_{2} \mathrm{O}_{6}$ were found in the literature review [28-30]. Following this approach in this paper, the hydration behaviour of a series of oxides of the type $\mathrm{Ca}_{7-\mathrm{x}} \mathrm{Sr}_{\mathrm{x}} \mathrm{ZrAl}_{6} \mathrm{O}_{18}$ using isothermal calorimetry at room temperature is presented. The hydration products were controlled by means of X-ray diffraction analysis, thermal analysis (DTA-TG-EGA) and scanning electron microscopy (SEM/EDS) of the cement stone.

\section{Experimental}

\section{Synthesis}

The synthesis of a series of oxides of the type $\mathrm{Ca}_{7-\mathrm{x}} \mathrm{Sr}_{\mathrm{x}}$ $\mathrm{ZrAl}_{6} \mathrm{O}_{18}$, where $x=0.3,0.6,1.0$, and the reference material with $x=0$ as undoped $\mathrm{Ca}_{7} \mathrm{ZrAl}_{6} \mathrm{O}_{18}$ was performed by a two-step firing procedure using two different sintering temperatures. In a first step, calcium carbonate $(99.81 \%$ $\mathrm{CaCO}_{3}$, Chempur), strontium carbonate $\left(99.00 \% \mathrm{SrCO}_{3}\right.$, Merck), $\alpha-\mathrm{Al}_{2} \mathrm{O}_{3}$ (99.8\% $\mathrm{Al}_{2} \mathrm{O}_{3}$, Across Organics) and zirconia $\left(98.08 \% \mathrm{ZrO}_{2}\right.$, Merck) powders were mixed with appropriate molar ratio of $\mathrm{CaO}, \mathrm{SrO}, \mathrm{Al}_{2} \mathrm{O}_{3}$ and $\mathrm{ZrO}_{2}$ oxides, and then, the mixtures were homogenized for $2 \mathrm{~h}$ in a ball mill and pressed into cylinders having a diameter of $2 \mathrm{~cm}$. All green pellets were calcined at $1300{ }^{\circ} \mathrm{C}$ for $10 \mathrm{~h}$. In a second step, solid-state sintering of the pellets made from the calcined powder at $1420{ }^{\circ} \mathrm{C}$ for $15 \mathrm{~h}$ resulted in phases $\mathrm{Sr}^{2+}$. doped $\mathrm{Ca}_{7} \mathrm{ZrAl}_{6} \mathrm{O}_{18}$. An intermediate grinding and mixing stage in order to improve homogeneity was necessary. As a final step, the reference $\mathrm{Ca}_{7} \mathrm{ZrAl}_{6} \mathrm{O}_{18}$ and $\mathrm{Sr}^{2+}$-doped $\mathrm{Ca}_{7}$ $\mathrm{ZrAl}_{6} \mathrm{O}_{18}$ sinters were ground to a fine powder using a mortar and pestle, and then, they were homogenized for $1 \mathrm{~h}$ in a ball mill. The samples were characterized by $\mathrm{X}$-ray powder diffraction using X'Pert ProPANalytical X-ray diffractometer. The XRD patterns of powdered samples were collected by step scanning with step of $0.02^{\circ}$ over the range $5^{\circ}$ $90^{\circ}$ at room temperature. The phases developed during sintering were compared and confirmed using search-match reference ICDD database. The pellets were also polished, coated with carbon and then analysed using Nova NanoSEM 200 scanning electron microscope.

\section{Cementitious paste preparation and methods of investigation}

The course of hydration of a series of oxides of the type $\mathrm{Ca}_{7-\mathrm{x}} \mathrm{Sr}_{\mathrm{x}} \mathrm{ZrAl}_{6} \mathrm{O}_{18}$, where $x=0.3,0.6,1.0$, and the reference material with $x=0$ as undoped $\mathrm{Ca}_{7} \mathrm{ZrAl}_{6} \mathrm{O}_{18}$ was investigated using isothermal microcalorimeter TAM Air (TA Instruments) by integrating the continuous heat flow signal during the 72-h hydration process. Calorimetric measurements of cementitious phases were taken using the 
in situ mixing treatments of powder with water with 1.0 of water/cement mass ratio (w/c) and temperature of $25^{\circ} \mathrm{C}$. All tests were performed by mixing the pastes inside the calorimeter to study the early hydration processes of cements. Two grams of dry powder was poured into a glass vial and water weighed into mounted syringes. Admix ampoule was introduced into the calorimeter prior mixing, thus equilibrating to isothermal environment. Mixing was done after equilibration inside the calorimeter to enable the quantitative access to the heat of the early hydration process. A second glass vial containing sand (providing the same heat capacity that the mass of binder paste) was used as an inert reference in the twin channel of calorimeter to ensure best stability of the baseline. Heat flow curves were normalized to the mass of total dry binder and reported in terms of power ( $\mathrm{mW} \mathrm{g}^{-1}$ dry binder) versus time (hours).

The hydration products and the thermal stability of hydrates were investigated by differential thermal analysis-thermogravimetric analysis-evolved gas analysis (DTA-TG-EGA), X-ray diffraction analysis and scanning electron microscopy-energy-dispersive spectroscopy (SEM-EDS) (mentioned above). For this purpose, the neat cement paste composed of $\mathrm{Ca}_{7-\mathrm{x}} \mathrm{Sr}_{\mathrm{x}} \mathrm{ZrAl}_{6} \mathrm{O}_{18}$, where $x=1.0$, and water with $w / c=1.0$ was homogenized by hand, in a glass baker. Sample in paste form was placed in sealed polyethylene bag and cured up to 21 days in a climatic chamber with the relative humidity maintained at $95 \%$ and temperature of $25^{\circ} \mathrm{C}$. As a next step, samples were dried by acetone quenching at specified intervals of time, i.e. $15 \mathrm{~min}, 0.5 \mathrm{~h}, 1 \mathrm{~h}, 24 \mathrm{~h}, 3$ days, 7 days, 14 days and 21 days. Dry powders were then analysed by XRD and thermal analysis. A simultaneous DTA-TG-EGA method (NETZSCH STA 449 F5 Jupiter coupled to QMS 403 D Aëolos) at a heating rate of $10{ }^{\circ} \mathrm{C} \min ^{-1}$ under a flow of $\mathrm{Ar}$ $\left(50 \mathrm{~mL} \mathrm{~min}^{-1}\right)$ was applied. The containers for samples and reference were corundum crucibles. The reference corundum crucible was kept empty during all DTA-TGEGA tests. The initial sample mass was $25 \mathrm{mg}$.

Characterization of microstructure evolution of cement paste by SEM was performed on the freshly broken surfaces of the hardened cement pastes after $24 \mathrm{~h}, 3$ days and 11 days of curing duration. The samples were coated with carbon in order to remove any charge.

\section{Results and discussion}

\section{Synthesis of the $\mathrm{Sr}^{2+}$-doped calcium zirconium aluminate cement}

The samples with different concentrations of strontia sintered at $1420{ }^{\circ} \mathrm{C}$ for $15 \mathrm{~h}$ were ground, and the phases were identified by XRD analysis. The X-ray diffraction results present no diffraction peaks of $\mathrm{SrO}$ and other Sr-bearing phases admixtures, e.g. strontium aluminates. Moreover, the peaks of $\mathrm{Ca}_{7} \mathrm{ZrAl}_{6} \mathrm{O}_{18}$ shifted gradually with increasing the content of $\mathrm{SrO}$, thus indicating that $\mathrm{Sr}^{2+}$ ions have been doped into $\mathrm{Ca}_{7} \mathrm{ZrAl}_{6} \mathrm{O}_{18}$ lattice to form the mixed oxides of the type $\mathrm{Ca}_{7-\mathrm{x}} \mathrm{Sr}_{\mathrm{x}} \mathrm{ZrAl}_{6} \mathrm{O}_{18}$ solid solutions, where $x=0.3$, $0.6,1.0$. The XRD pattern for concentration of strontia $x=1.0$ unhydrated composite will be presented later together with the powder XRD patterns for the $\mathrm{Ca}_{7-\mathrm{x}}$ $\mathrm{Sr}_{\mathrm{x}} \mathrm{ZrAl}_{6} \mathrm{O}_{16}(x=1.0)$-based cement paste. Effect of $\mathrm{Sr}^{2+}$ ions doping on $\mathrm{Ca}_{7} \mathrm{ZrAl}_{6} \mathrm{O}_{18}$ lattice was confirmed by comparing the values of the observed peaks with their standard values as per JCPDS No. 98-018-2622 [31]. It is found that with the increase in the SrO content, a shift in the lines corresponds to a somewhat larger unit cell for the "pure" undoped $\mathrm{Ca}_{7} \mathrm{ZrAl}_{6} \mathrm{O}_{18}$ in comparison with $\mathrm{Sr}$ doped $\mathrm{Ca}_{7} \mathrm{ZrAl}_{6} \mathrm{O}_{18}$ solid solutions since the substituting $\mathrm{Sr}^{2+}$ ion is larger than $\mathrm{Ca}^{2+}$ (1.13 vs. $\left.0.99 \AA\right)$ [28]. Figure $1 \mathrm{a}, \mathrm{b}$ shows the results of the SEM and EDS observations of $\mathrm{Ca}_{7-\mathrm{x}} \mathrm{Sr}_{\mathrm{x}} \mathrm{ZrAl}_{6} \mathrm{O}_{16}(x=1.0)$ sinter heat treated at $1420{ }^{\circ} \mathrm{C}$ for $15 \mathrm{~h}$. Almost pure crystal phase of $\mathrm{Sr}^{2+}$. doped calcium zirconium aluminate with some amount of accessory $(\mathrm{Ca}, \mathrm{Sr}) \mathrm{ZrO}_{3}$ was found in the SEM microstructure. The EDS spectrum was taken on the region where strontium formed a solid solution within the matrix, which is shown as grey region in SEM image (Fig. 1b). The mass percentage of elements determined by the quantitative EDS microanalysis in SEM is 26.73 mass\% Ca, 12.82 mass\% Sr, 12.96 mass\% Zr, 20.36 mass\% $\mathrm{Al}$ and 27.14 mass\% O. This results closely relate to the concentration of elements in the stoichiometric composition, designed as $\left(\mathrm{Ca}_{6} \mathrm{Sr}\right) \mathrm{ZrAl}_{6} \mathrm{O}_{18}$.

\section{Hydration and crystalline hydration products of the $\mathrm{Sr}^{2+}$-doped calcium zirconium aluminate cement}

The results of isothermal calorimetric experiment (Figs. 2, 3), X-ray diffraction analysis (Figs. 4, 5), simultaneous thermal analysis (Figs. 6, 7a, b) and scanning electron microscopy (Figs. 8-10) were used to study the evolution of phase composition during the process of hydration of $\mathrm{Sr}^{2+}$-doped calcium zirconium aluminate cement paste with w/c of 1.0 at room temperature. Figures 2 and 3 exhibit the influence of chemical and structural modification of $\mathrm{Ca}_{7} \mathrm{ZrAl}_{6} \mathrm{O}_{18}$ phase induced by strontium doping upon the calorimetric curves at constant value of water/ cement ratio. Figure $2 b$ demonstrates the rate of heat evolution for the blended cements over a 72-h period. As the $\mathrm{Ca}_{7} \mathrm{ZrAl}_{6} \mathrm{O}_{18}$ phase was doped with $\mathrm{Sr}^{2+}$ ions $\left(\mathrm{Ca}_{7-\mathrm{x}} \mathrm{Sr}_{\mathrm{x}} \mathrm{ZrAl}_{6} \mathrm{O}_{18} ; x=0\right.$ (as undoped, reference), 0.3, $0.6,1.0)$, the intensity of the peak heat rate decreased gradually with increasing strontium content (Fig. 2a). 


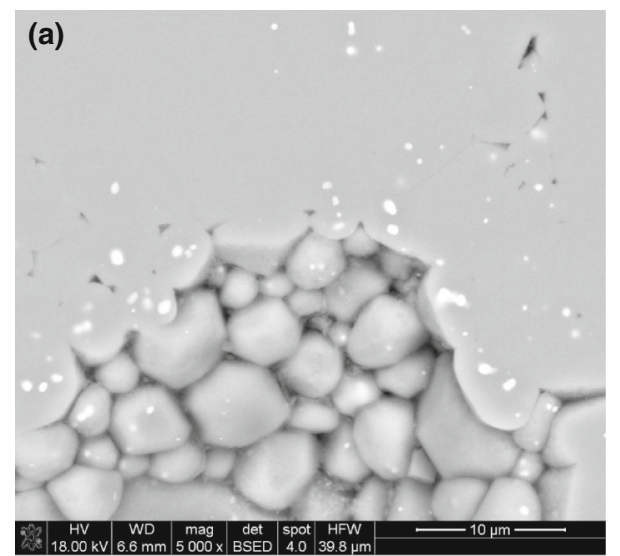

(b) $\mathrm{Al} \quad$ Sr-doped $\mathrm{Ca}_{7} \mathrm{ZrAl}_{6} \mathrm{O}_{18}$

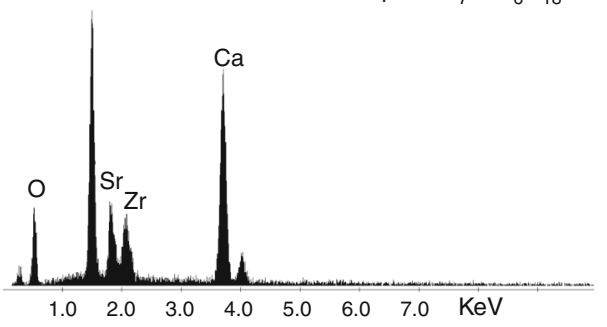

Fig. 1 a SEM image of the microstructure of as-synthesized $\mathrm{Sr}^{2+}$ doped $\mathrm{Ca}_{7} \mathrm{ZrAl}_{6} \mathrm{O}_{18}$ sample heat treated at $1420{ }^{\circ} \mathrm{C}$ for $15 \mathrm{~h}$. b EDS spectrum and quantitative composition analysis of grey region in (a)

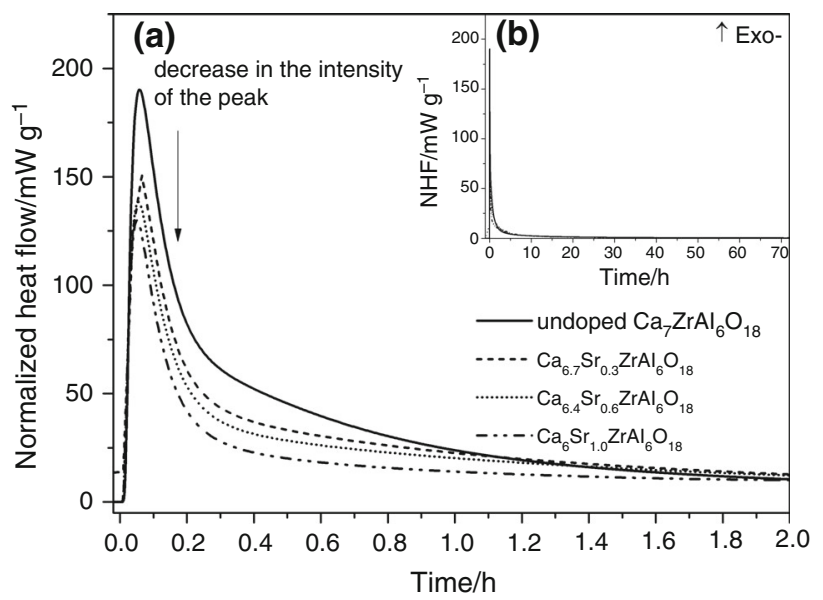

Fig. 2 Heat flow curves as a function of hydration time (a the first $2 \mathrm{~h}$; $\mathbf{b}$ the period of $72 \mathrm{~h}$ ) of the undoped reference $\mathrm{Ca}_{7} \mathrm{ZrAl}_{6} \mathrm{O}_{18}$ and the $\mathrm{Ca}_{7-\mathrm{x}} \mathrm{Sr}_{\mathrm{x}} \mathrm{ZrAl}_{6} \mathrm{O}_{16}(x=0.3,0.6$ and 1.0) cement pastes prepared with 1.0 of w/c (water-to-cement) ratio and hydrated at room temperature, normalized to mass of binder paste (with in situ mixing condition)

This figure presents not typical heat evolution rate with only one peak that corresponds to initial reactions which follow the mixing of the cement with water. There is also not any occurrence of induction period observed; hence, the hydration reaction starts immediately after mixing of

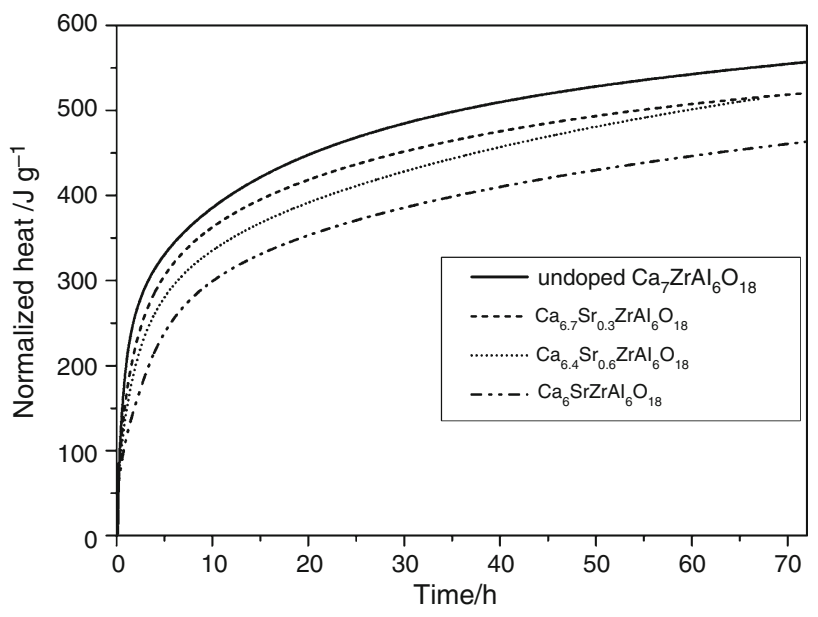

Fig. 3 Cumulative heat curves as a function of hydration time of the undoped reference $\mathrm{Ca}_{7} \mathrm{ZrAl}_{6} \mathrm{O}_{18}$ and the $\mathrm{Ca}_{7-\mathrm{x}} \mathrm{Sr}_{\mathrm{x}} \mathrm{ZrAl}_{6} \mathrm{O}_{16}(x=0.3$, 0.6 and 1.0) cement pastes prepared with 1.0 of w/c (water-to-cement) ratio and hydrated at room temperature for the period of $72 \mathrm{~h}$

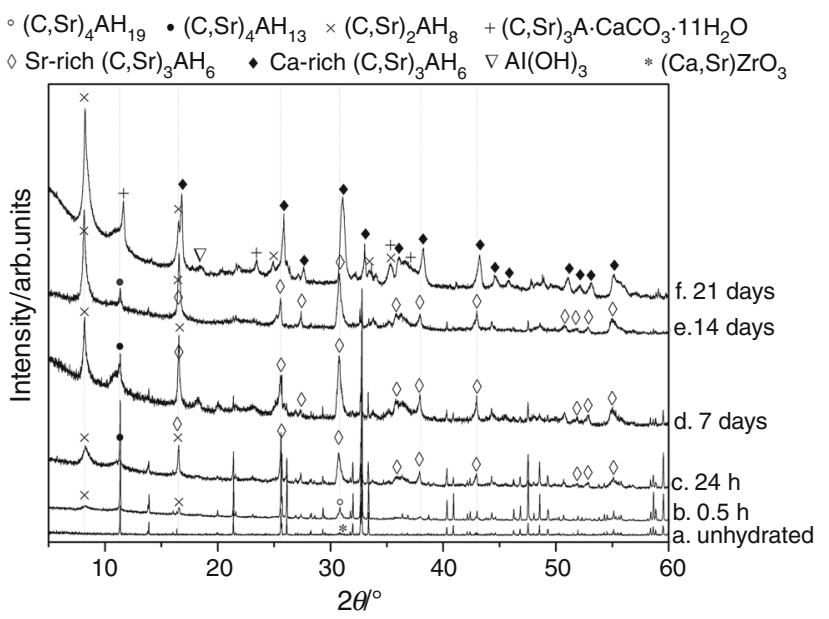

Fig. 4 Powder XRD patterns for the $\mathrm{Ca}_{7-\mathrm{x}} \mathrm{Sr}_{\mathrm{x}} \mathrm{ZrAl}_{6} \mathrm{O}_{16}(x=1.0)$ based cement paste prepared with 1.0 of w/c ratio and hydrated at

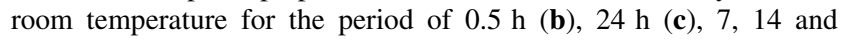
21 days $(\mathbf{d}-\mathbf{f})$. a Unhydrated $\mathrm{Ca}_{7-\mathrm{x}} \mathrm{Sr}_{\mathrm{x}} \mathrm{ZrAl}_{6} \mathrm{O}_{16}(x=1.0)$ phase

these cementitious phases with water at room temperature. The first peak corresponds to initial reactions which follow the mixing of the cement with water. It records the heat of wetting, dissolution, hydration of $\mathrm{Sr}^{2+}$-doped calcium zirconium aluminate and the early formation of hydration products. There is no occurrence of the dormant period or the induction period in the heat flow curve (Fig. 2). After about $2 \mathrm{~h}$, the hydration reaches a steady state and future hydration is diffusion controlled. Thus, the mass transport of water and dissolved ions through the hydration barrier controls hydration process. No other exothermic peaks were also registered during $72 \mathrm{~h}$ of experiment. Figure 3 shows an integration of the heat evolution over a period of $72 \mathrm{~h}$. It is particularly easy to make the very clear conclusions that for given strontium- 


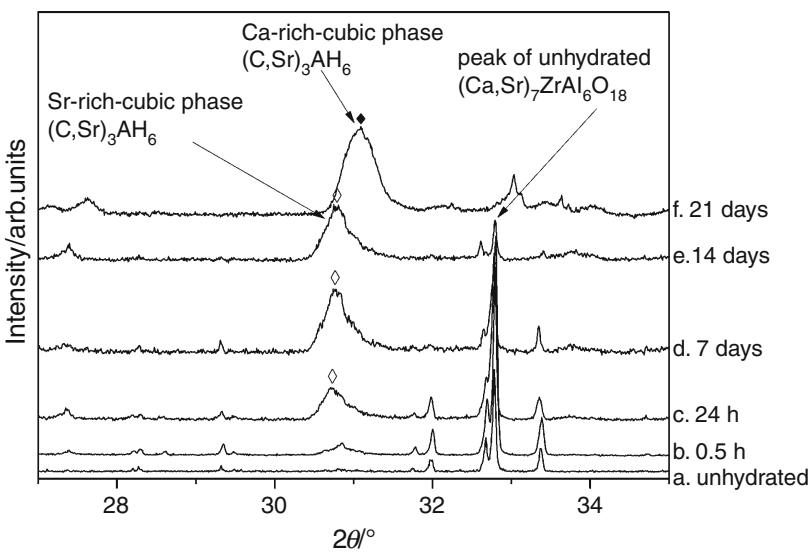

Fig. 5 Powder XRD patterns for the $\mathrm{Ca}_{7-\mathrm{x}} \mathrm{Sr}_{\mathrm{x}} \mathrm{ZrAl}_{6} \mathrm{O}_{16}(x=1.0)$ based cement pastes collected at $2 \theta$ from $27^{\circ}$ to $35^{\circ}$

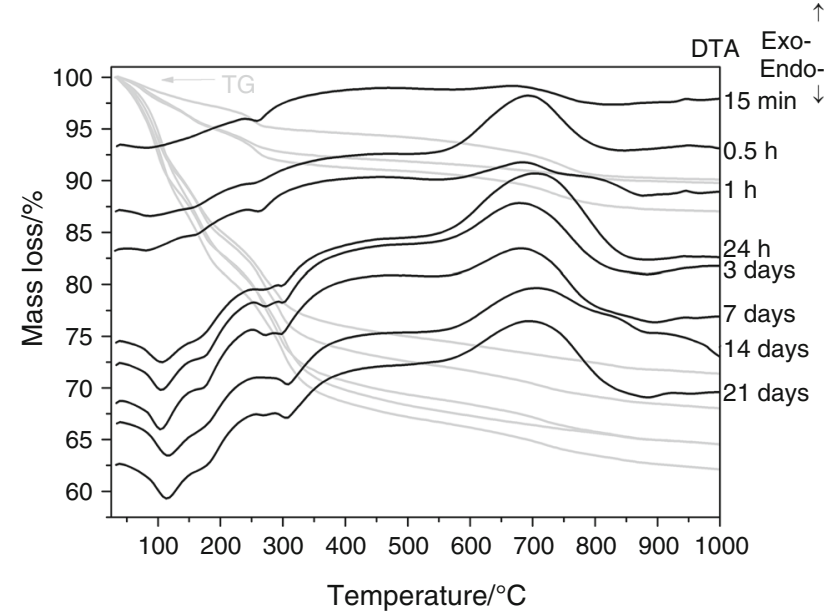

Fig. 6 Simultaneous TG (in grey)/DTA (in black) curves of cementitious binder samples measured in argon at flow rate $50 \mathrm{~mL} \mathrm{~min}{ }^{-1}$ (heating rate $10{ }^{\circ} \mathrm{C} \mathrm{min}^{-1}$, initial mass $25 \mathrm{mg}$ )

modified cements all hydration produces less heat as compared to pure $\mathrm{Ca}_{7} \mathrm{ZrAl}_{6} \mathrm{O}_{18}$. According to the initial structural model given by Fukuda et al. [5], the highly disordered crystal structure of $\mathrm{Ca}_{7} \mathrm{ZrAl}_{6} \mathrm{O}_{18}$ with the five types of positions of $\mathrm{Ca}$ atoms and four types of $\mathrm{AlO}_{4}$ tetrahedra was found. $\mathrm{Ca}$ atoms are located between $\left[\mathrm{Al}_{6} \mathrm{O}_{18}\right]$ rings created by interconnected six $\mathrm{AlO}_{4}$ tetrahedra in this structure. The incorporation of $\mathrm{Sr}$ (instead of Ca) causes both chemical and structural modifications of $\mathrm{Ca}_{7} \mathrm{ZrAl}_{6} \mathrm{O}_{18}$, thus influencing its hydration kinetics.

The course of heat evolution during hydration of cementitious phases described by means of calorimetric curves plotting the rate of heat evolution in $\mathrm{mW} \mathrm{g}^{-1}$ can be pertained to changes in the phase composition of the hardened cement pastes controlled by means of X-ray diffraction (XRD).

The mineralogical composition of the acetone quenched hydrated cementitious pastes determined by XRD is
Ion current/A

(a) $m / Z=18\left(\mathrm{H}_{2} \mathrm{O}\right)$
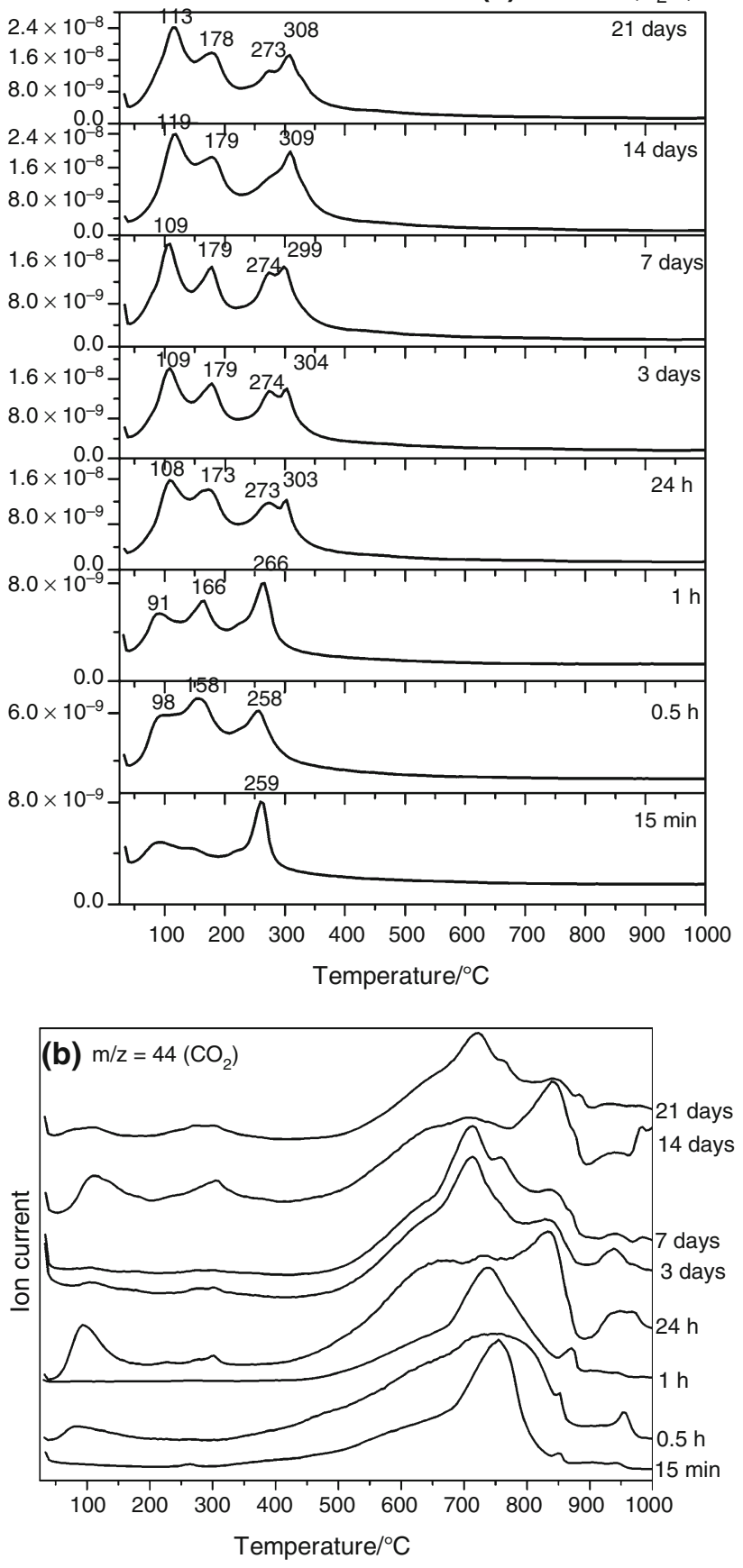

Fig. 7 Gas evolution curves for representative mass spectroscopic ion fragments of $\mathrm{H}_{2} \mathrm{O}$ (a) and $\mathrm{CO}_{2}$ (b) vapours during the thermal decomposition of the cementitious binder samples in flowing argon, measured in situ by online coupled TG/DTA-EGA-MS system (Ar flow $50 \mathrm{~mL} \mathrm{~min}{ }^{-1}$, heating rate $10{ }^{\circ} \mathrm{C} \mathrm{min}^{-1}$ )

presented in Figs. 4 and 5. The original sample is an unhydrated compound (Fig. 4a) that undergoes a phase transformation when it reacts with water at room temperature. The hydration process occurs in the $\mathrm{Sr}^{2+}$-doped calcium zirconium aluminate cement at various time intervals $(0.5,24 \mathrm{~h} ; 7,14$ and 21 days). As indicated in 


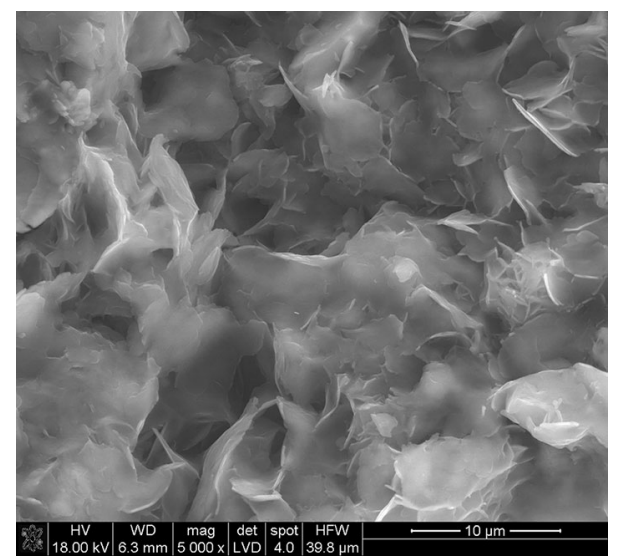

Fig. 8 SEM images of the fracture surface of 24-h hydrated $\mathrm{Sr}^{2+}$. doped calcium zirconium aluminate cement paste (room temperature)

Eq. (1), the overall reaction proceeds as chemical changes take place leading to the formation of two separate products $(\mathrm{C}, \mathrm{Sr})_{4} \mathrm{AH}_{19}$ and $(\mathrm{C}, \mathrm{Sr})_{2} \mathrm{AH}_{8}$ at the early stage of hydration. Since strontium ions can substitute the calcium in the hexagonal "pure" $\mathrm{C}-\mathrm{A}-\mathrm{H}$ and $\mathrm{AFm}$ phases $[30,32,33]$, broadening of the diffraction peaks caused by structural disorder of layered metastable hydrates [34] was observed.

\section{Hydration}

$2(\mathrm{Ca}, \mathrm{Sr})_{7} \mathrm{ZrAl}_{6} \mathrm{O}_{18}+59 \mathrm{H}_{2} \mathrm{O} \rightarrow 2\left(\left[(\mathrm{Ca}, \mathrm{Sr})_{2} \mathrm{Al}(\mathrm{OH})_{6}\right] \cdot \mathrm{OH}\right.$ $\left.\cdot 6 \mathrm{H}_{2} \mathrm{O}\right)+5\left(\left[(\mathrm{Ca}, \mathrm{Sr})_{2} \mathrm{Al}(\mathrm{OH})_{6}\right]\left[\mathrm{Al}(\mathrm{OH})_{4}\right] \cdot 3 \mathrm{H}_{2} \mathrm{O}\right)$

$+2 \mathrm{ZrO}_{2} 2(\mathrm{C}, \mathrm{Sr})_{7} \mathrm{~A}_{3} \mathrm{Z}+59 \mathrm{H}$

$\rightarrow(\mathrm{C}, \mathrm{Sr})_{4} \mathrm{AH}_{19}+5(\mathrm{C}, \mathrm{Sr})_{2} \mathrm{AH}_{8}+2 \mathrm{Z}$

The typical crystalline phases of first hydration products were hexagonal tetracalcium aluminate 19-hydrate $\left((\mathrm{C}, \mathrm{Sr})_{4} \mathrm{AH}_{19}\right)$ and dicalcium aluminate hydrate $\left((\mathrm{C}, \mathrm{Sr})_{2}\right.$ $\left.\mathrm{AH}_{8}\right)$ that were observed after about $0.5 \mathrm{~h}$ of curing in cementitious paste as evidenced from the characteristic diffraction peaks centred at specific angles $2 \theta=30.868^{\circ}$ $(d=2.89448 \AA)$ and $2 \theta=8.2787^{\circ} \quad(d=10.67150 \AA)$. This is in good agreement with JCPDS cards No. 00-014628 and No. 00-045-0564 for $\mathrm{C}_{4} \mathrm{AH}_{19}$ and $\mathrm{C}_{2} \mathrm{AH}_{8}$, respectively. Nevertheless, the $\mathrm{X}$-ray diffraction patterns of $(\mathrm{C}, \mathrm{Sr})_{4} \mathrm{AH}_{19}$ and $(\mathrm{C}, \mathrm{Sr})_{2} \mathrm{AH}_{8}$ are very close making no further clear distinction between these two hydration products.

As time progresses, $(\mathrm{C}, \mathrm{Sr})_{4} \mathrm{AH}_{19}$ losses part of its interlayer water to form $(\mathrm{C}, \mathrm{Sr})_{4} \mathrm{AH}_{13}$, according to Eq. (2):

\section{Partial dehydration}

$$
\begin{aligned}
& 2\left(\left[(\mathrm{Ca}, \mathrm{Sr})_{2} \mathrm{Al}(\mathrm{OH})_{6}\right] \cdot \mathrm{OH} \cdot 6 \mathrm{H}_{2} \mathrm{O}\right) \\
& \rightarrow 2\left(\left[(\mathrm{Ca}, \mathrm{Sr})_{2} \mathrm{Al}(\mathrm{OH})_{6}\right] \cdot \mathrm{OH} \cdot 3 \mathrm{H}_{2} \mathrm{O}\right)+2\left(3 \mathrm{H}_{2} \mathrm{O}\right) \\
& (\mathrm{C}, \mathrm{Sr})_{4} \mathrm{AH}_{19} \rightarrow(\mathrm{C}, \mathrm{Sr})_{4} \mathrm{AH}_{13}+6 \mathrm{H}
\end{aligned}
$$

The formation of tetracalcium aluminium 13-hydrate $\left.(\mathrm{C}, \mathrm{Sr})_{4} \mathrm{AH}_{13}\right)$ between $24 \mathrm{~h}$ and 14 days in the $\mathrm{Ca}_{7-\mathrm{x}} \mathrm{Sr}_{\mathrm{x}}$ $\mathrm{ZrAl}_{6} \mathrm{O}_{16} \quad(x=1.0)$-based hydrated cement paste was identified by $\mathrm{X}$-ray diffraction analysis, as shown in Fig. 4c-e. The diffraction patterns show the most detectable peak (the " $100 \%$ peak") of $\mathrm{C}_{4} \mathrm{AH}_{13}$ at about $2 \theta=11.1638^{\circ}(d=7.91968 \AA)$ that is in good agreement with reference data (JCPDS card No. 00-011-0203).

The interlayer exchange of $\mathrm{OH}^{-}$by $\mathrm{CO}_{3}{ }^{2-}$ proceeds via a stepwise manner such as shown in Eq. 3. This exchange is accompanied by a shift in the position of the diffraction maxima from $2 \theta=11.164^{\circ}$ to $2 \theta=11.6293^{\circ}$ ( $d=7.60964 \AA$ ). The latest one belongs to the calcium carboaluminate hydrate $\mathrm{C}_{3} \mathrm{~A} \cdot \mathrm{CaCO}_{3} \cdot 11 \mathrm{H}_{2} \mathrm{O}$ (JCPDS cards No. 00-036-0377) which has been identified in 21-day cured cementitious paste.

\section{Carbonation}

$$
\begin{aligned}
& 2\left(\left[(\mathrm{Ca}, \mathrm{Sr})_{2} \mathrm{Al}(\mathrm{OH})_{6}\right] \cdot \mathrm{OH} \cdot 3 \mathrm{H}_{2} \mathrm{O}\right)+\mathrm{CO}_{2} \\
& \rightarrow 2\left(\left[(\mathrm{Ca}, \mathrm{Sr})_{2} \mathrm{Al}(\mathrm{OH})_{6}\right] \cdot 0.5 \mathrm{CO}_{3} \cdot 2.5 \mathrm{H}_{2} \mathrm{O}\right)+2 \mathrm{H}_{2} \mathrm{O} \\
& (\mathrm{C}, \mathrm{Sr})_{4} \mathrm{AH}_{13}+\mathrm{CO}_{2} \rightarrow(\mathrm{C}, \mathrm{Sr})_{4} \mathrm{AC}^{\mathrm{C}} \mathrm{H}_{11}+2 \mathrm{H} \\
& (\mathrm{C}, \mathrm{Sr})_{4} \mathrm{AH}_{13}+\mathrm{CO}_{2} \rightarrow(\mathrm{C}, \mathrm{Sr})_{3} \mathrm{~A} \cdot \mathrm{CaCo}_{3} \cdot 11 \mathrm{H}_{2} \mathrm{O}+2 \mathrm{H}
\end{aligned}
$$

In the conversion reaction, compounds $(\mathrm{C}, \mathrm{Sr})_{4} \mathrm{AH}_{19}$ (or $\left.(\mathrm{C}, \mathrm{Sr})_{4} \mathrm{AH}_{13}\right)$ and $(\mathrm{C}, \mathrm{Sr})_{2} \mathrm{AH}_{8}$ redissolved or interact to give $(\mathrm{C}, \mathrm{Sr})_{3} \mathrm{AH}_{6}$, hydrogarnet, along with additional $\mathrm{AH}_{3}$, which over time tends increasingly to approximate to gibbsite (Eqs. 4a-c).

\section{Transformation}

$$
\begin{aligned}
& 2\left(\left[(\mathrm{Ca}, \mathrm{Sr})_{2} \mathrm{Al}(\mathrm{OH})_{6}\right] \cdot \mathrm{OH} \cdot 6 \mathrm{H}_{2} \mathrm{O}\right) \\
& +\left[(\mathrm{Ca}, \mathrm{Sr})_{2} \mathrm{Al}(\mathrm{OH})_{6}\right]\left[\mathrm{Al}(\mathrm{OH})_{4}\right] \cdot 3 \mathrm{H}_{2} \mathrm{O} \\
& \rightarrow 2\left(\mathrm{Ca}, \mathrm{Sr}_{3} \mathrm{Al}_{2}\left(\mathrm{O}_{4} \mathrm{H}_{4}\right)_{3}+15 \mathrm{H}_{2} \mathrm{O}\right. \\
& (\mathrm{C}, \mathrm{Sr})_{4} \mathrm{AH}_{19}+(\mathrm{C}, \mathrm{Sr})_{2} \mathrm{AH}_{8} \rightarrow 2(\mathrm{C}, \mathrm{Sr})_{3} \mathrm{AH}_{6}+15 \mathrm{H}
\end{aligned}
$$

$2\left(\left[(\mathrm{Ca}, \mathrm{Sr})_{2} \mathrm{Al}(\mathrm{OH})_{6}\right] \cdot \mathrm{OH} \cdot 3 \mathrm{H}_{2} \mathrm{O}\right)+\left[(\mathrm{Ca}, \mathrm{Sr})_{2} \mathrm{Al}(\mathrm{OH})_{6}\right]$ $\left[\mathrm{Al}(\mathrm{OH})_{4}\right] \cdot 3 \mathrm{H}_{2} \mathrm{O} \rightarrow 2\left(\mathrm{Ca}, \mathrm{Sr}_{3} \mathrm{Al}_{2}\left(\mathrm{O}_{4} \mathrm{H}_{4}\right)_{3}+9 \mathrm{H}_{2} \mathrm{O}\right.$ $(\mathrm{C}, \mathrm{Sr})_{4} \mathrm{AH}_{13}+(\mathrm{C}, \mathrm{Sr})_{2} \mathrm{AH}_{8} \rightarrow 2(\mathrm{C}, \mathrm{Sr})_{3} \mathrm{AH}_{6}+9 \mathrm{H}$ 
$3\left(\left[(\mathrm{Ca}, \mathrm{Sr})_{2} \mathrm{Al}(\mathrm{OH})_{6}\right]\left[\mathrm{Al}(\mathrm{OH})_{4}\right] \cdot 3 \mathrm{H}_{2} \mathrm{O}\right)$

$\rightarrow 2\left(\mathrm{Ca}, \mathrm{Sr}_{3} \mathrm{Al}_{2}\left(\mathrm{O}_{4} \mathrm{H}_{4}\right)_{3}+2 \mathrm{Al}(\mathrm{OH})_{3}+9 \mathrm{H}_{2} \mathrm{O}\right.$

$3(\mathrm{C}, \mathrm{Sr})_{2} \mathrm{AH}_{8} \rightarrow 2(\mathrm{C}, \mathrm{Sr})_{3} \mathrm{AH}_{6}+\mathrm{AH}_{3}+9 \mathrm{H}$

The powder X-ray patterns of 24-h-14-day cured cementitious paste and 21-day cured cementitious paste indicate that at least two different kinds of components of hydrogarnet were present in these samples (Fig. 4c-f). In essence, the diffraction patterns of a sample of $\mathrm{Ca}_{7-x} \mathrm{Sr}_{\mathrm{x}}$ $\mathrm{ZrAl}_{6} \mathrm{O}_{16}(x=1.0)$, treated with water within the curing time range between $24 \mathrm{~h}$ and 14 days (Fig. 4c-e) and hydrated up to 21 days (Fig. 4f), show the presence of two series of similar lines that are located very close together, indicating that two hydration products having a similar crystal structure are formed. Going into details, two isostructural hydrates were formed like $\mathrm{Sr}$-rich and $\mathrm{Ca}$-rich cubic phase $(\mathrm{C}, \mathrm{Sr})_{3} \mathrm{AH}_{6}$. The position of characteristic line of $\mathrm{Sr}$-rich cubic phase $(\mathrm{C}, \mathrm{Sr})_{3} \mathrm{AH}_{6}$ is very close to the location of Ca-rich one, but it was found at lower values of 2theta. All diffraction lines in powder patterns belonging generally to cubic phase, as compared with standard X-ray diffraction pattern of $\mathrm{C}_{3} \mathrm{AH}_{6}$ (JCPDS card No. 01-0710735), are shifted to lower values of 2 theta. There are two phenomena in the presented results. Firstly, the three most intense peaks at $16.7921^{\circ}, 38.1904^{\circ}$ and $31.0501^{\circ}$ are due to the Ca-rich cubic phase $(\mathrm{C}, \mathrm{Sr})_{3} \mathrm{AH}_{6}$ in the XRD pattern of $\mathrm{Ca}_{7-\mathrm{x}} \mathrm{Sr}_{\mathrm{x}} \mathrm{ZrAl}_{6} \mathrm{O}_{16}(x=1.0)$ cement paste prepared with $1.0 \mathrm{of}$ w/c ratio and hydrated at room temperature for the period of 21 days (Fig. 4f). Secondly, Fig. 4c-e clearly emphasizes the formation of a second hydrogarnet phase, Sr-rich cubic (C,Sr) ${ }_{3} \mathrm{AH}_{6}$, as evidenced from the diffraction peaks positioned at $16.5731^{\circ}, 37.9245^{\circ}$ and $30.8052^{\circ}$ of $2 \theta$ for 14-day cured sample, given as an example. The significant $2 \theta$ peak shifts to lower angles when $\mathrm{Sr}^{2+}$ was used, with respect to peaks from "pure" $\mathrm{C}_{3} \mathrm{AH}_{6}$, and formation of both Sr-rich $(\mathrm{C}, \mathrm{Sr})_{3} \mathrm{AH}_{6}$ and Ca-rich $(\mathrm{C}, \mathrm{Sr})_{3} \mathrm{AH}_{6}$-type solid solutions could be attributed to induced crystal-field effects due to the different ionic size of $\mathrm{Ca}^{2+}(0.99 \AA)$ compared with $\mathrm{Sr}^{2+}(1.13 \AA)$ [28]. Hence, Sr-rich $(\mathrm{C}, \mathrm{Sr})_{3} \mathrm{AH}_{6}$ was stable within a reaction period from $24 \mathrm{~h}$ to 14 days (Fig. $4 \mathrm{c}-\mathrm{e}$ ). The consecutive formation of two separate solid solution members, supported by Ref. [28], one close to the strontium ( $\mathrm{Sr}$-rich $\left.(\mathrm{C}, \mathrm{Sr})_{3} \mathrm{AH}_{6}\right)$ and the other to the calcium $\left(\mathrm{Ca}\right.$-rich $\left.(\mathrm{C}, \mathrm{Sr})_{3} \mathrm{AH}_{6}\right)$ end, leads to the conclusion that the strontium reacted first, by reason of its greater solubility, leaving a solution richer in lime to form later. Shifting to the left from the standard XRD peaks of $\mathrm{C}_{3} \mathrm{AH}_{6}$ due to replacing $\mathrm{Ca}^{2+}$ with $\mathrm{Sr}^{2+}$ is evident from both Fig. $5 \mathrm{c}-\mathrm{f}$ and Table 1 . Moreover, residues of unhydrated $(\mathrm{Ca}, \mathrm{Sr})_{7} \mathrm{ZrAl}_{6} \mathrm{O}_{18}$ were observed up to 14 days of curing, and this phase continues to hydrate slowly over the next 7 days (Fig. 5e-f).
Table 1 Reference data for "pure" $\mathrm{C}_{3} \mathrm{AH}_{6}$ (JCPDS card No. 01-071$0735)$ and the related $2 \theta\left[^{\circ}\right]$ positions and $d[\AA]$ values obtained in this work

\begin{tabular}{|c|c|c|}
\hline \multicolumn{2}{|l|}{ This work } & \multirow{2}{*}{$\begin{array}{l}\text { Reference "pure" } \\
\mathrm{C}_{3} \mathrm{AH}_{6}\end{array}$} \\
\hline $\begin{array}{l}14 \text { days of hydration } \\
\text { Sr-rich }(\mathrm{C}, \mathrm{Sr})_{3} \mathrm{AH}_{6}\end{array}$ & $\begin{array}{l}21 \text { days of hydration } \\
\text { Ca-rich }(\mathrm{C}, \mathrm{Sr})_{3} \mathrm{AH}_{6}\end{array}$ & \\
\hline \multicolumn{3}{|c|}{$2 \theta$ positions and $d$ values } \\
\hline $16.5731^{\circ}, 5.34468 \AA$ & $16.7921^{\circ}, 5.27551 \AA$ & $17.259^{\circ}, 5.13393 \AA$ \\
\hline $37.9245^{\circ}, 2.37056 \AA$ & $38.1904^{\circ}, 2.35468 \AA$ & $39.206^{\circ}, 2,29596 \AA$ \\
\hline $30.8052^{\circ}, 2.90023 \AA$ & $31.0501^{\circ}, 2.87789 \AA$ & $31.797^{\circ}, 2.81197 \AA$ \\
\hline
\end{tabular}

\section{Thermal stability of hydration products of the $\mathrm{Sr}^{2+}$ - doped calcium zirconium aluminate cement paste}

The simultaneous TG/DTA measurements show several decomposition stages of the $\mathrm{Sr}^{2+}$-doped calcium zirconium aluminate cement paste after curing time period of $15 \mathrm{~min}$ to 21 days (Fig. 6). The progress of cement hydration consumes water and produces hydrates; thus, the highest loss of mass due to the evaporation of the water chemically bonded to $\mathrm{C}-\mathrm{Sr}-\mathrm{A}-\mathrm{H}$ phases was achieved after 21 days of moist curing. The total mass loss due to decomposition of the cement paste between about 25 and $1000{ }^{\circ} \mathrm{C}$ is 9.89 , $10.23,12.98,28.71,32.05,35.53,35.59$ and $38.00 \%$ of the initial mass, corresponding to the length of curing time according to thermogravimetric analysis results displayed as TG curves (in grey) for samples cured as long as $15 \mathrm{~min}$, $0.5 \mathrm{~h}, 1 \mathrm{~h}, 24 \mathrm{~h}, 3$ days, 7 days, 14 days and 21 days, respectively. These curves can be compared to the in situ analysis of the evolved gaseous species by the online coupled EGA-MS system. Main evolution curves of $\mathrm{H}_{2} \mathrm{O}$ $(\mathrm{m} / \mathrm{z}=18)$ and $\mathrm{CO}_{2}(\mathrm{~m} / \mathrm{z}=44)$ are also shown as ion current versus temperature in Fig. 7a, b. Evolution of $\mathrm{H}_{2} \mathrm{O}$ shows parallel run to the DTA curves having local maximums at the same temperature values. Nevertheless, the endothermic dehydration peaks are more sensitively detected by the MS than DTA curves and the characteristic peaks of evolution of $\mathrm{H}_{2} \mathrm{O}$ are clearly visible in all the samples. In the temperature range of $25-1000{ }^{\circ} \mathrm{C}$, the peaks attributed to $\mathrm{H}_{2} \mathrm{O}$ are apparently strengthened, thus confirming the water consumed in the formation of the hydration products with hydration time. The signals for $\mathrm{H}_{2} \mathrm{O}$ change from one peak at $259{ }^{\circ} \mathrm{C}$ to strong peaks between 90 and $310^{\circ} \mathrm{C}$. The EGA peak attributed to $\mathrm{H}_{2} \mathrm{O}$ at 259,258 or $266{ }^{\circ} \mathrm{C}$ was due to the decomposition reaction of the crystalline $(\mathrm{C}, \mathrm{Sr})_{4} \mathrm{AH}_{19}$, which was formed preferentially during the first $15 \mathrm{~min}$ and exists up to ca. $1 \mathrm{~h}$ of hydration (Fig. 7a). Next, fraction of bound water of $(\mathrm{C}, \mathrm{Sr})_{4} \mathrm{AH}_{19}$ was lost, and within a time range between $24 \mathrm{~h}$ and 7 days, the $(\mathrm{C}, \mathrm{Sr})_{4} \mathrm{AH}_{19}$ lost part of its interlayer water to form $(\mathrm{C}, \mathrm{Sr})_{4} \mathrm{AH}_{13}$. At the temperature of 273 or 
$274{ }^{\circ} \mathrm{C}$, the peaks attributed to $\mathrm{H}_{2} \mathrm{O}$ due to the decomposition reaction of $(\mathrm{C}, \mathrm{Sr})_{4} \mathrm{AH}_{13}$ were observed in the mass spectroscopic gas-evolution curves of the cementitious pastes hydrated between $24 \mathrm{~h}$ and 7 days (Fig. 7a). Starting from 14 days of hydration, this peak was not observed clearly in the $\mathrm{m} / \mathrm{z} 18$ curve that proves the partial disappearance of $(\mathrm{C}, \mathrm{Sr})_{4} \mathrm{AH}_{13}$ phase including its carbonation and formation of the crystalline $(\mathrm{C}, \mathrm{Sr})_{4} \mathrm{~A} \bar{C} \mathrm{H}_{11}$ phase within a time range between 14 and 21 days. The peak of tetracalcium aluminium carbonate hydrate coincides with the peak $(\mathrm{C}, \mathrm{Sr})_{2} \mathrm{AH}_{8}$ at about $178{ }^{\circ} \mathrm{C}$. The EGA peak attributed to $\mathrm{H}_{2} \mathrm{O}$ evolution at $158,166,173,179$ or $178{ }^{\circ} \mathrm{C}$ was due to the decomposition reaction of the crystalline $(\mathrm{C}, \mathrm{Sr})_{2} \mathrm{AH}_{8}$, which was detected within a time range between $0.5 \mathrm{~h}$ and 21 days (Fig. 7a). The gradual shift of these peaks to higher temperature as curing time progresses may be caused by an increase in the degree of crystallinity this hydrate.

The water release from Sr-rich $(\mathrm{C}, \mathrm{Sr})_{3} \mathrm{AH}_{6}$ and Ca-rich $(\mathrm{C}, \mathrm{Sr})_{3} \mathrm{AH}_{6}$ begins as soon as the conversion of metastable hydrates to the stable higher-density phases starts after $24 \mathrm{~h}$ of hydration and it is visible as EGA peak at ca. $300{ }^{\circ} \mathrm{C}$ in the evolution curves of $\mathrm{H}_{2} \mathrm{O}$ of the $\mathrm{Sr}^{2+}$ doped calcium zirconium aluminate cement paste hydrated within a time range between $24 \mathrm{~h}$ and 21 days (Fig. 7a). Despite the fact that the cubic phases Sr-rich $(\mathrm{C}, \mathrm{Sr})_{3} \mathrm{AH}_{6}$ and Ca-rich $(\mathrm{C}, \mathrm{Sr})_{3} \mathrm{AH}_{6}$ were clearly distinguished from the XRD patterns of both 14-day and 21-day hydrated cement pastes as shown in Figs. 4, 5, there is no clear difference in the EGA peaks at 309 and $308{ }^{\circ} \mathrm{C}$ (Fig. 7a), respectively.

According to the DTA, TG and EGA curves, the loss of mass due to the decomposition of $\mathrm{AH}_{3}$ gel takes place below $120{ }^{\circ} \mathrm{C}$ with the broad endothermic effect in all blended cement pastes but is clearly visible as a strong effect in samples cured for at least $24 \mathrm{~h}$. The decomposition step due to the dehydration of crystalline gibbsite $\mathrm{Al}(\mathrm{OH})_{3}$ is observed in Fig. $7 \mathrm{a}$ as the EGA peaks at $273{ }^{\circ} \mathrm{C}$ that precede the peak of Ca-rich $(\mathrm{C}, \mathrm{Sr})_{3} \mathrm{AH}_{6}$ under longterm curing age up to 21 days. The evolution of $\mathrm{CO}_{2}$ gas from the carbonated $\mathrm{Sr}^{2+}$-doped calcium zirconium aluminate cement consisted of different stages with broad EGA peaks (Fig. 7b).

\section{Microstructural investigations of the $\mathrm{Sr}^{2+}$-doped calcium zirconium aluminate cement paste}

The microstructure of hydration products of the $\mathrm{Sr}^{2+}$ doped calcium zirconium aluminate binder paste was examined by SEM/EDS (Figs. 8-10a). The SEM micrographs in Fig. 8 show that the flake-like crystals of $\mathrm{C}-\mathrm{Sr}-$ $\mathrm{A}-\mathrm{H}$ and amorphous gels are the major hexagonal

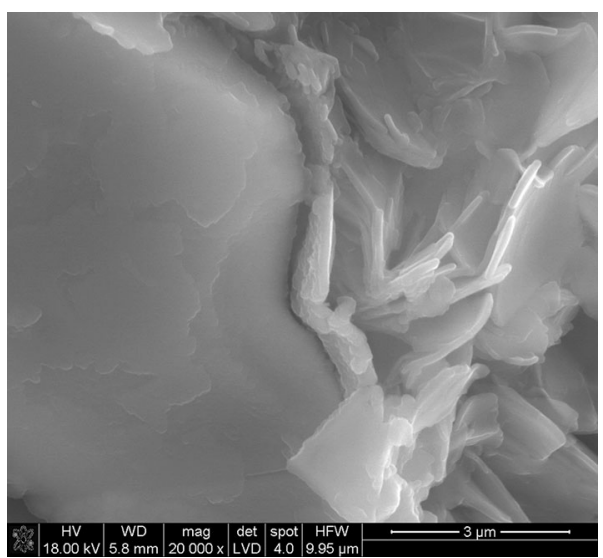

Fig. 9 SEM images of the fracture surface of 3-day hydrated $\mathrm{Sr}^{2+}$. doped calcium zirconium aluminate cement paste (room temperature)

(a)

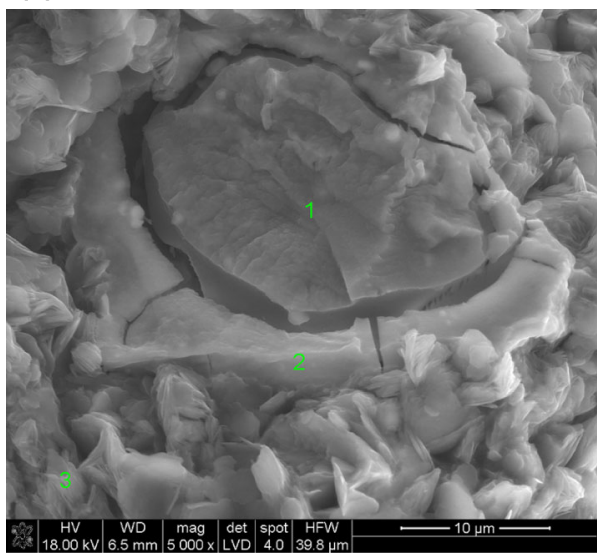

(b)

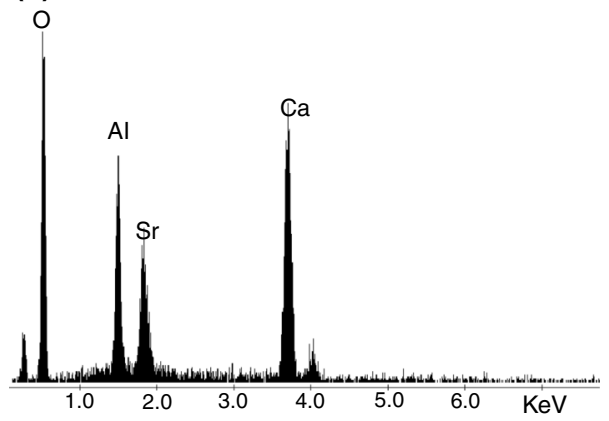

Fig. 10 SEM images of the fracture surface of 11-day hydrated $\mathrm{Sr}^{2+}$ doped calcium zirconium aluminate cement paste (room temperature). Spot 1-3 EDS analysis. a EDS spectrum of sample in the micro area 3

hydration products and they were formed at age of $24 \mathrm{~h}$ at room temperature. As hydration proceeds, the unhydrated grain core is continuously consumed to form hydration products and the hydrated product of the $\mathrm{Sr}^{2+}$-doped calcium zirconium aluminate compound in a grain of cement 
Table 2 EDS analyses of the points in Fig. 10a (unit: atom\%)

\begin{tabular}{lccc}
\hline Element & Spectrum 1 & Spectrum 2 & Spectrum 3 \\
\hline $\mathrm{O}$ & 64.35 & 75.00 & 73.68 \\
$\mathrm{Al}$ & 9.57 & 6.58 & 8.78 \\
$\mathrm{Sr}$ & 5.28 & 6.01 & 3.71 \\
$\mathrm{Zr}$ & 11.95 & 7.00 & 0.11 \\
$\mathrm{Ca}$ & 8.84 & 5.41 & 13.72 \\
\hline
\end{tabular}

adheres firmly to the unhydrated core of the grains of cement as shown in Figs. 9 and 10a. The characteristics of the hydrates were examined by EDS analysis after the SEM examination, as illustrated in Fig. 10b and Table 2. These results show that the hydrated matrix contains calcium, strontium and aluminium, which can be related to the calcium strontium aluminium hydrates $(\mathrm{C}-\mathrm{Sr}-\mathrm{A}-\mathrm{H})$. There was also a clear segregation of zirconium within the reaction zone generated from unhydrated grain core of $(\mathrm{Ca}, \mathrm{Sr})_{7} \mathrm{ZrAl}_{6} \mathrm{O}_{18}$ to the hydrated matrix $\mathrm{C}-\mathrm{Sr}-\mathrm{A}-\mathrm{H}$ (points 1-2-3).

\section{Conclusions}

1. Since no diffraction peaks of $\mathrm{SrO}$ and other Sr-bearing phases, e.g. strontium aluminates, can be detected in samples and the peaks of $\mathrm{Ca}_{7} \mathrm{ZrAl}_{6} \mathrm{O}_{18}$ shift gradually with the composition, it indicates that $\mathrm{SrO}$ has been doped into $\mathrm{Ca}_{7} \mathrm{ZrAl}_{6} \mathrm{O}_{18}$ lattice to form uniform solid solution.

2. Intensity of the first peak of heat evolution is gradually reduced as the $x$ value in the $\mathrm{Ca}_{7-\mathrm{x}} \mathrm{Sr}_{\mathrm{x}} \mathrm{ZrAl}_{6} \mathrm{O}_{18}$ $(x=0.3,0.6,1.0)$ formula increases.

3. The hydration heat first peak of the mixed oxides of the type $6 \mathrm{CaO} \cdot \mathrm{SrO} \cdot 3 \mathrm{Al}_{2} \mathrm{O}_{3} \cdot \mathrm{ZrO}_{2}$ is generated simultaneously with both the wetting of cement grains and the formation of Sr-doped hexagonal $\mathrm{C}_{4} \mathrm{AH}_{13-19}$ and $\mathrm{C}_{2} \mathrm{AH}_{8}$ hydration products.

4. Including strontium ions in the solid solutions of unstable hexagonal hydrates could effectively inhibit the conversion from both $\mathrm{C}_{4} \mathrm{AH}_{13-19}$ and $\mathrm{C}_{2} \mathrm{AH}_{8}$ to stable $\mathrm{C}_{3} \mathrm{AH}_{6}$ and $\mathrm{AH}_{3}$ products.

5. The new phase $\mathrm{C}_{3} \mathrm{~A} \cdot \mathrm{CaCO}_{3} \cdot 11 \mathrm{H}_{2} \mathrm{O}\left(\mathrm{C}_{4} \mathrm{~A} \bar{C} \mathrm{H}_{11}\right)$ was found in this system due to the activity of carbon dioxide; the formation of $\mathrm{C}_{4} \mathrm{AH}_{13-19}$ and $\mathrm{C}_{2} \mathrm{AH}_{8}$ is prohibited and the generation of stable cubic phase is delayed in the early hydration process.

6. Two hydrogarnet phases, one Sr-rich $(\mathrm{C}, \mathrm{Sr})_{3} \mathrm{AH}_{6}$ and the other Ca-rich $(\mathrm{C}, \mathrm{Sr})_{3} \mathrm{AH}_{6}$, were formed due to the inevitable and irreversible conversion of metastable hydrates.
Acknowledgements The research was performed at Faculty of Materials Science and Ceramics of AGH and was supported by the Project No. 11.11.160.617.

\section{Compliance with ethical standards}

Conflict of interest The authors declare that they have no conflict of interest.

Open Access This article is distributed under the terms of the Creative Commons Attribution 4.0 International License (http://crea tivecommons.org/licenses/by/4.0/), which permits unrestricted use, distribution, and reproduction in any medium, provided you give appropriate credit to the original author(s) and the source, provide a link to the Creative Commons license, and indicate if changes were made.

\section{References}

1. Pacewska B, Nowacka M. Studies of conversion progress of calcium aluminate cement hydrates by thermal analysis method. J Therm Anal Calorim. 2014;117(2):653-60.

2. Boris R, Antonovič V, Keriene J, Stonys R. The effect of carbon fiber additive on early hydration of calcium aluminate cement. J Therm Anal Calorim. 2016;125:1061-70.

3. Berezhnoi AS, Kordyuk RA. Melting diagram of the system $\mathrm{CaO}-\mathrm{Al}_{2} \mathrm{O}_{3}-\mathrm{ZrO}_{2}$. Dopov Akad Nauk URSR. 1963;10:1344-7.

4. Berezhnoi AS, Tarnopol'skaya RA. Calcium aluminozirconatea new hydraulic binder. Neorg Mater Akad Nauk. 1968;4:2151-4.

5. Fukuda K, Iwata T, Nishiyuki K. Crystal Structure, structural disorder, and hydration behavior of calcium zirconium aluminate, $\mathrm{Ca}_{7} \mathrm{ZrAl}_{6} \mathrm{O}_{18}$. Chem Mater. 2007;19(15):3726-31.

6. Madej D, Szczerba J, Nocuń-Wczelik W, Gajerski R. Hydration of $\mathrm{Ca}_{7} \mathrm{ZrAl}_{6} \mathrm{O}_{18}$ phase. Ceram Int. 2012;38(5):3821-7.

7. Madej D, Szczerba J. Study of the hydration of calcium zirconium aluminate $\left(\mathrm{Ca}_{7} \mathrm{ZrAl}_{6} \mathrm{O}_{18}\right)$ blended with reactive alumina by calorimetry, thermogravimetry and other methods. J Therm Anal Calorim. 2015;121:579-88.

8. Szczerba J, Madej D, Śnieżek E, Prorok R. The application of DTA and TG methods to investigate of the non-crystalline hydration products of $\mathrm{CaAl}_{2} \mathrm{O}_{4}$ and $\mathrm{Ca}_{7} \mathrm{ZrAl}_{6} \mathrm{O}_{18}$ compounds. Thermochim Acta. 2013;567(10):40-5.

9. Madej D, Szczerba J, Nocuń-Wczelik W, Gajerski R, Hodur K. Studies on thermal dehydration of the hydrated $\mathrm{Ca}_{7} \mathrm{ZrAl}_{6} \mathrm{O}_{18}$ at different water-solid ratios cured at $60^{\circ} \mathrm{C}$. Thermochim Acta. 2013;569:55-60.

10. Madej D, Szczerba J, Dul K. Phase transformation during the decomposition of hydrated calcium zirconium aluminate $\left(\mathrm{Ca}_{7}\right.$ $\left.\mathrm{ZrAl}_{6} \mathrm{O}_{18}\right)$ paste subjected to various dehydration temperatures. Thermochim Acta. 2014;597(10):27-34.

11. Madej D, Szczerba J. Preparation of $\mathrm{Al}_{2} \mathrm{O}_{3}-\mathrm{CaAl}_{12} \mathrm{O}_{19}-\mathrm{ZrO}_{2}$ composite ceramic material by the hydration and sintering of $\mathrm{Ca}_{7} \mathrm{ZrAl}_{6} \mathrm{O}_{18}$-reactive alumina mixture. Ceram-Silik. 2016;60(1):27-33.

12. Szczerba J, Madej D, Dul K, Bobowska P. $\mathrm{Ca}_{7} \mathrm{ZrAl}_{6} \mathrm{O}_{18}$ acting as a hydraulic and ceramic bonding in the $\mathrm{MgO}-\mathrm{CaZrO}_{3}$ dense refractory composite. Ceram Int. 2014;40(5):7315-20.

13. Taylor HFW. Cement chemistry. 2nd ed. London: Thomas Telford; 1997.

14. Hewlett PC. Lea's chemistry of cement and concrete. 4th ed. London: Elsevier Science and Technology Books; 2004.

15. Barnes P, Bensted J. Structure and Performance of Cements. 2nd ed. London: CRC Press; 2001. 
16. Флейшер ГЮ, Токарчук ВВ, Свідерський ВА. The effect of nitrogen-containing organic admixtures on the chemical processes of cement hardening. East Eur $\mathbf{J}$ Enterp Technol. 2016;1(6(79)):46-54.

17. Hill RL. The study of hydration of fly ash in the presence of calcium nitrate and calcium formate. Doctoral dissertation. Texas; 1994 (unpublished research work).

18. Bushnell-Watson SM, Sharp JH. The detection of the carboaluminate phase in hydrated high alumina cements by differential thermal analysis. Thermochim Acta. 1985;93:613-6.

19. George CM. Industrial aluminous cements. In: Barnes P, editor. Structure and Performance of Cements. London: Appl Sci; 1983. p. $415-70$.

20. Midgley HG. Measurement of high-alumina cement-calcium carbonate reactions using DTA. Clay Miner. 1984;19:857-64.

21. Das SK, Mitra A, Dad Padar PK. Thermal analysis of hydrated calcium aluminates. J Therm Anal. 1996;47:765-74.

22. Fryda H, Scrivener KL, Chanvillard G. Relevance of laboratory tests to field applications of calcium aluminate cement concretes. In: Mangabhai RJ, Glasser FP, editors. Calcium aluminate cements. London: IOM Communications; 2001. p. 227-46.

23. Ewais EMM, Khalil NM, Amin MS, Ahmed YMZ, Barakat MA. Utilization of aluminum sludge and aluminum slag (dross) for the manufacture of calcium aluminate cement. Ceram Int. 2009;35:3381-8.

24. Abo-El-Enein SA, Heikal M, Amin MS, Negm HH. Reactivity of dealuminated kaolin and burnt kaolin using cement kiln dust or hydrated lime as activators. Constr Build Mater. 2013;47:1451-60.

25. Hashem FS, Amin MS, El-Gamal SMA. Improvement of acid resistance of Portland cement pastes using rice husk ash and cement kiln dust as additives. $\mathrm{J}$ Therm Anal Calorim. 2013;111:1391-8.
26. Amin MS, El-Gamal SMA, Hashem FS. Fire resistance and mechanical properties of carbon nanotubes - clay bricks wastes (Homra) composites cement. Constr Build Mater. 2015;98:237-49.

27. Abo-El-Enein SA, Hashem FS, Amin MS, Sayed DM. Physicochemical characteristics of cementitious building materials derived from industrial solid wastes. Constr Build Mater. 2016;126:983-90.

28. Prodjosantoso AK, Kennedy BJ, Hunter BA. Phase separation induced by hydration of the mixed $\mathrm{Ca} / \mathrm{Sr}$ aluminates $\mathrm{Ca}_{3-\mathrm{x}} \mathrm{Sr}_{\mathrm{x}}$ $\mathrm{Al}_{2} \mathrm{O}_{6}$. Cement Concrete Res. 2002;32:647-55.

29. Prodjosantoso AK, Kennedy BJ. Synthesis and evolution of the crystalline phases in $\mathrm{Ca}_{1-\mathrm{x}} \mathrm{Sr}_{\mathrm{x}} \mathrm{Al}_{2} \mathrm{O}_{4}$. J Solid State Chem. 2002;168:229-36.

30. Pöllmann H, Kaden R. Mono- (strontium-, calcium-) aluminate based cements. In: Fentiman CH, Mangabhai RJ, Scrivener KL, editors. Calcium aluminates proceedings of the international conference. Garston: IHS BRE Press; 2014. p. 99-108.

31. ICDD and ICSD PDF-2 database products.

32. Atkins M, Glasser FP. Application of Portland cement-based materials to radioactive waste immobilization. Waste Manage. 1992;12:105-31.

33. Evans NDM. Binding mechanisms of radionuclides to cement. Cement Concrete Res. 2008;38:543-53.

34. Britto S, Joseph S, Kamath PV. Distinguishing crystallite size effects from those of structural disorder on the powder X-ray diffraction patterns of layered materials. J Chem Sci. 2010;122(5):751-6. 